\title{
The Development of Ecotourism Model at Natural Attractions of Tete Batu Village in East Lombok
}

\author{
* Nofiarli \\ Student Geography of Science, Padang State University, INDONESIA
}

Email: nofiarli483@ymail.com

*Corresponding Author, Received: January 15, 2018, Revised: March 02. 2018, Accepted: May 20, 2018

This is an open acces article distributed under the Creative Commons 4.0 Attribution License, wich permits unrestricted use, Distribution, and reproduction in any medium provided the original work is properly cited @2017 by author and Universitas Negeri Padang

\begin{abstract}
Tourist village of Tete Batu is located at Sikur District in East Lombok Regency, Nusa Tenggara Barat Province. With its scenic beauty along the southern foot of Rinjani Mountain and its green, natural, beautiful and mild countryside atmosphere, Tete Batu Village offers economic potential to its community. Tourism sector needs a good tourism development that can develop existing potential with a maximum result. This research was aimed to find the effect of natural attraction development in Tete Batu Village that adopted Ecotourism Model in the interest of increasing the number of tourist arrivals. Technique of data analysis being used was SWOT analysis with qualitative approach. There were two types of data that were collected, namely primary and secondary data. Primary data was obtained through field observation, interview and questionnaire, while secondary data was collected from related literature study. The result showed that natural attractions in Tete Batu village could be developed by using Ecotourism model because its condition could attract tourists and the management was done by the society and based on local nature and culture.
\end{abstract}

Keywords: Ecotourism Model,Tourist Attraction of Tete Batu Village

\section{Introduction}

Tourism in Nusa Tenggara Barat is often called as Halal tourism especially in Lombok Island. The title is attached after Lombok managed to win first place in World Halal Tourism event in 2015 and 2016 and was awarded as world's best halal honeymoon tour in 2016. So, muslim tourists began to look at Indonesia, especially Lombok as their tourism destination. Tourist attractions in Lombok provide security and convenient service to the tourists in order to enjoy their vacation in ease, secure and halal.

East Lombok Regency is located in east end of Lombok Island with a total area of 2.679,88 km² which consists of $1.605 .55 \mathrm{~km}^{2}$ mainland $(59.91 \%)$ and $1.074,33 \mathrm{~km}^{2}$ oceans $(40.09 \%)$. The total area of land in East Lombok Regency is $33.88 \%$ of the total area of Lombok Island or $7.97 \%$ of the total land area in Nusa Tenggara Barat Province. The land in East Lombok is including highlands and lowland which stretch up to coastal area. Highlands are mostly located at the northern region, in Gunung Rinjani's National Park with a peak height of 3,726 meters above sea level, while central to southern regions is formed by the lowland. East Lombok Regency consists of 20 districts, namely Aikmel, Jerowaru, Keruak, Labuhan Haji, Masbagik, Montong Gading, Pringgabaya, Pringgasela, Sakra Barat, Sakra Timur, Sakra, Sambelia, Selong, Sembalun, Sikur, Suela, Sukamulia, Suralaga, Terara and Wanasaba (Central Bureau of Statistics of East Lombok, 2016). 
In East Lombok Regency, there are tourist villages suh as Sapit Village, Sugian Village, Labuhan Lombok Village, Lendang Nangka Village, Tete Batu Villageand Sembalun Village. Tourist attraction in Tete Batu Village sites in Siklur District around the foot of Mount Rinjaniat an altitude of 700 metres above sea level. Tete Batu is formed by elongated canyon and terraced rice fields like soil contour which is the main enticement that lures many tourists to visit the village.

A concept change from world tourism to special interest tourism, known as ecotourism, is a great opportunity for our country that has various natural potential because many tourists tend to prefer natural and cultural attractions to other attractions. Ecotourism is a popular term which stands for ecological tourism. Ecotourism is a responsible travel to natural areas that conserves the environment and improves the economy, culture and tradition of the local people (Tuwo, 2011). According to Anonymous source (2000) in Edi Mulyadi (2010), Ecotourism is a form of tourism whose purpose is to conserve the environment and improve the life and well-being of the local people. Originally, ecotourism was done only by nature lovers who want intended destinations remain intact and sustainable including local people's culture and prosperity.

Ecotourism offers a unity of integrated travel value between enjoying natural beauty and the effort to conserve it. Ecotourism plays an important role in providing solutions for solving the problems in tourism development. The main focus of this tourism model is based on basic tourism potentials that prioritize the concept of natural and cultural conservation (Dirawan,2008). Ecotourism is an informative or a participative tour to a natural or unnatural and cultural environment which aims to secure its natural and cultural continuity. So, ecotourism emphasizes ecological or natural sustainability.

Conceptually, ecotourism can be defined as a sustainable tourism development concept that intends to support the efforts to preserve the environment (nature and culture) and improve local people's involvement in management so that they can be economically benefited from it. In the perspective of management, ecotourism is a tourism program which is designed for natural places or areas and managed according to principles of sustainable nature and economy for the sake of supporting environmental conservation (nature and culture) and improving well-being of the local people (Marpaung Happy, 2000). Ecotourism program directly gives access to related parties to see, know, and experience nature and culture of local people, gives economic benefits and is psychologically easily accepted in social life of the society.

According to Page and Dowling (2000) in Doddy Soedigdo (2013), there are 5 core principles in Ecotourism concept: (1) Nature based, (2) Ecologically suitainable, (3) Environmentally educative, (4) Locally beneficial, and (5) Generates tourist satisfaction. Furthermore, the Regulation of Minister of Home Affair Number 33 Year 2009 mentioned 4 types of local ecotourism: (a) Marine Ecotourism, (b) Forest Ecotourism, (c) Mountain Ecotourism, and (d) Karst Ecotourism.

Dias Satria (2009) said that although the model proposes positive values, it also arises critics and problems regarding its implementation. Some of critics are: (1) The tourism's negative effect on environment. Despite its conservation based principles, some rules are still broken because some local people and tourists have lack of knowledge and awareness related to ecotourism concept, (2) Society's low participation in ecotourism. Most of local people only play as audiences and are unable to actively participate in, especially economic, process of the tourism, (3) wrong perception and management of ecotourism concept because of the lack of government's role and supervision in developing tourism areas. Ecotourism model is put forward as one of strategies to help solving social and economic problems of local societies and as one of effective tools for environmental conservation (Garrod, 2003). The development of ecotourism in Tete Batu Village cause an interaction between local community and tourist area. This interaction gives a dynamic effect on tourist area and is expected to improve the quality of local community's life and conserve the natural and cultural heritage.

\section{Method}

This research was conducted in tourist attractions in Tete Batu Village which is one of villages in East Lombok Regency. The research employed field observation, interview, questionnaire and literature study to collect the data. The data consisted of primary data about potential offers of ecotourism attractions and secondary data about general condition of the research location and socio-economy of the people. This research was a descriptive qualitative method which adopted SWOT analysis technique. SWOT analysis is a technique 
that analyze internal and external factors of the environment being studied. The factors were decided based on the aspects of Strengths, Weaknesses, Opportunities and threats of an organization. Therefore, the possibilities of comprehensive alternatives of strategy can be determined (Freddy Rangkuti, 2005). Internal analysis was including strengths and weaknesses of the internal environment, while external analysis was done by analyzing opportunities and threats of the external environment which might influence ecotourism development model at tourist attractions in Tete Batu Village. The result of those analysis was transferred into matrix diagram by using weighting and rating. Weight values being used are from 0 (not important) to 1 (very important). Rating values being used are from 1 (low) to 4 (very high).

\section{Results and Discussion}

\section{Profile of Natural Tourist Attractions at Tete Batu Village East Lombok}

Tourist village of Tete Batu is located in Sikur District, East Lombok Regency, Nusa Tenggara Barat Province. The distance of the village from Mataram is about $60 \mathrm{~km}$. Tete Batu Village is one of villages where people can enjoy the scenic beauty as hills and paddy fields at the southern foot of Mount Rinjani. The topography of Tete Batu village shows a formation of elongated canyon like soil contour that presents a wonderful green and fertile terraced paddy fields panorama. The fields' outline is very visible from any part of village. Then, there are some low hills that are used as scenic viewpoints for viewing paddy fields and farmer's activity. Moreover, located at the altitude of 700 meters above sea level, Tete Batu village is cool, refreshing and pollution-free. Other than the fields, the village is also dressed by not less beautiful natural scenery like steep hills that merge with the forest line and waterfall. One of forest tourism in Tete Batu vilage is Hutan Kera (monkey forest) which is located at the northern village. When entering the forest, tourists are welcomed by melodious singing of hundreds of bird species and rows of trees that are neatly arranged. The forest is also inhabited by lutungor langur (Trachypithecus Auratus), long-tailed black monkey species which is one of original inhabitants of the forest.

The village's mild and cool weather is very suitable for people who want to rest before continuing their tour to other destinations. A river that runs along the foot of Mount Rinjani is a good place for swimming and relaxation. There is also Jukut or Jeruk Manis Waterfall whose height is 40 meters and its waster is very fresh and clear. This waterfall is situated at Mount Rinjani, precisely at the northern area of National Park Conservation of Mount Rinjani. To visit the waterfall, it will take \pm 1.5 hours only by foot. All along the road to the waterfall, the tourist will pass local people houses and be pleased by terrace like paddy fields. There are also other waterfalls in Tete Batu Village such as Ulem - ulem Waterfall, Burung Wale Waterfall, Kokok Duren Waterfall and Seme Deye Waterfall.

The people of Tete Batu are starting to aware of tourism, so some programs that support tourism development have been held. Other than tourist attractions, there are some interesting offers given by local people to tourists. They are invited to directly experience the local activity. For example, they are directly coming down to paddy field, cutting grass, and feeding cows or roasting coffee beans, pounding, subliming, and brewing the coffee. There are other local activities that can be experienced by the tourists such as making bamboo wicker craft, Tracking Mount Rinjani with interesting natural scenery. Moreover, in Tete Batu Village there is a place of mushroom cultivation. It is located around the village area. There the tourist can see the process of seeding of mushroom seed and putting it into baglocks. Then, the tourist can also see how local people prepare and cook the mushroom in the kitchen. Tete Batu village is also one of best tobacco producer. Furthermore, it also has plantation of horticultural crops such as nutmeg commodity. One of nutmeg productions ready for consumption and souvenir is candied nutmeg. Lombok's original tradition is Sasak tradition. This tradition is originated from Hinduism and still practiced in Tete Batu Village. Another tradition that is still practicing by the local people is syukuran bendungan (dam thanksgiving) or in Sasak language called Nyelamet Pengempel which can be a tourist attraction. The authenticity of Tete Batu tradition is included in tourism package that is arranged by the actors of tourism. In other words, Tete Batu tries to offer different tourist package from other tourist attractions and its people are ready to welcome the tourists. 
This tourist village has also prepared complete accommodation for staying. There are 13 inns and home stays. To reach Tete Batu Village, tourists can use two alternatives, by renting cars or using public transportation. Renting cars will be rather expensive and there are only few public transportation heading to the village. There is also traditional transportation such as horse-drawn carriage or Cidomo in Sasak language. The village roads are still dirt roads. Tete Batu Village has been developing for tourism and had stopped once. In 1990s, when tourists were rarely seen in other regions, there were many foreign tourists milling about Tete Batu Village. Now, Tete Batu Village develops to be one of favorite tourist attraction especially in East Lombok and as halal tourist attraction in Nusa Tenggara Barat in General. However, due to the influence of modernization and globalization the rural nuances begin to diminish. Moreover, facility and infrastructure is inadequate so that this village should be developed based on ecotourism model which is focus on conserving the environments (nature and culture) and improving local people's participation in management. So, they can economically benefited by the program.

\section{Analysis of External and Internal Factors of Ecotourism Development of Natural Attractions in Tete Batu Lombok}

\section{Internal Factor}

\section{Strength}

1) Scenic beauty and natural countryside atmosphere

2) Society's high commitment to conserve the nature

3) An open characteristic of local people towards strangers (foreigners)

4) Traditional and cultural uniqueness of local people

\section{Weaknesses}

1) lack of accessibility to tourist attraction in Tete Batu village

2) Inadequate supportive infrastructures of tourism (transportation, communication, health facility, and money changer)

3) low quality and quantity of human resources for tourism management

4) inadequate capital or fund for developing the tourism

\section{External Factor}

\section{Opportunities}

1) Geographical position of Tete Batu Village as a transit points for the tourists to visit other attractions

2) Fast development of information and communication technologies eases tourists to directly search for informationabout tourist attractions

3) High potential and interest of the tourists

4) government's policy regarding halal tourism give an opportunity to develop the tourism

\section{Threats}

1) lack of government's attention to improve transportation facility

2) Lack of security and comfort for the tourists

3) A decrease of local people's religious and cultural values

4) Lack of private's and government's investments to develop tourist attractions 
Table 1. Analysis of Internal Factors of Ecotourism Model at Natural attractions in Tete Batu Village

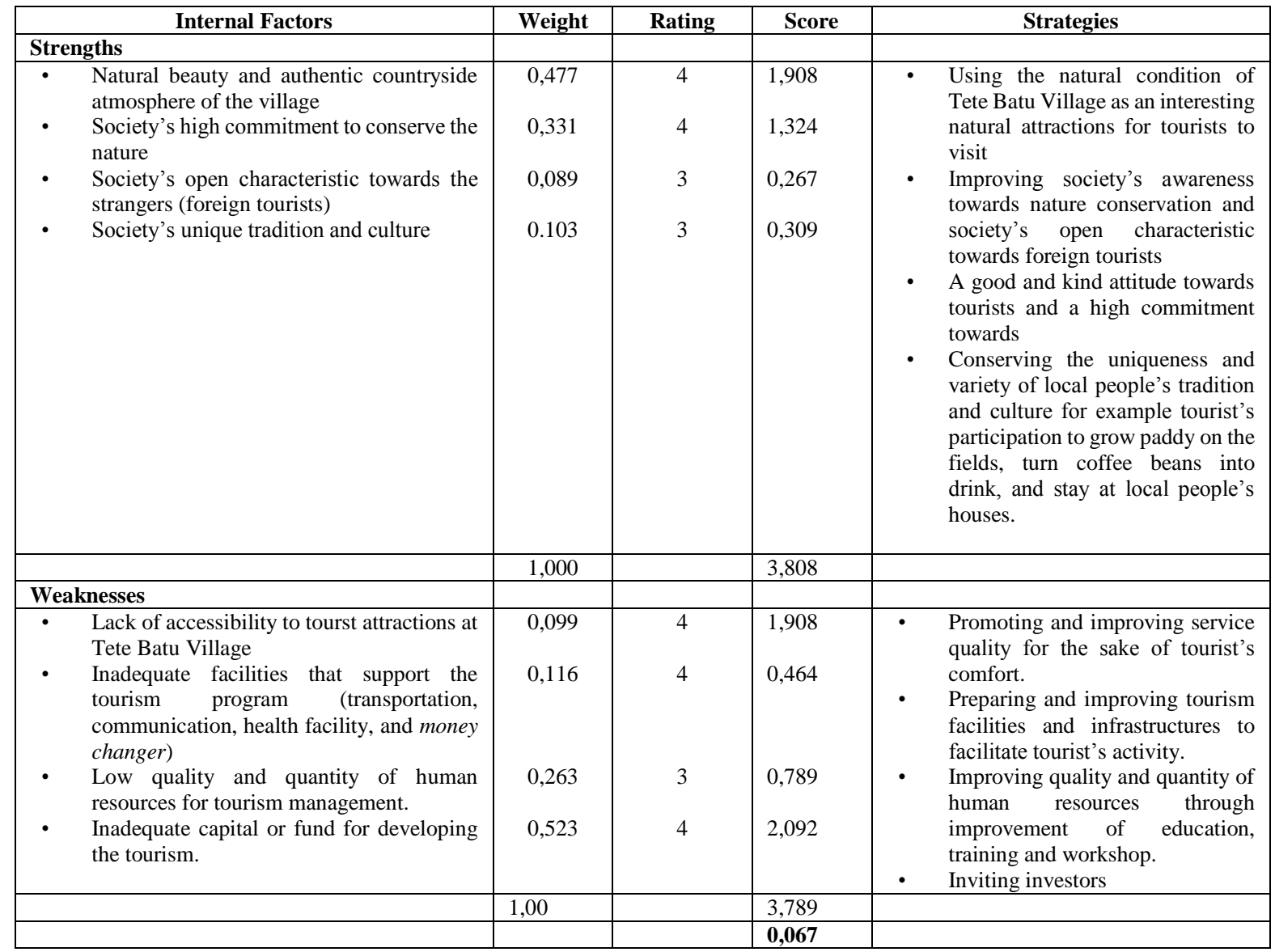

After conducting SWOT analysis, based on the each weight value between strengths and weaknesses, it can be concluded that strengths' value is a bit higher than weaknesses'. So, strengths can be optimized and weaknesses can be suppressed by proposed strategies. The same goes to opportunities. Opportunities weight value is higher than threats' value. So, effective strategies are needed to develop tourist village of Tete Batu by using ecotourism model. Based on SWOT analysis above, ecotourism based development of tourist natural attractions at Tete Batu can be done through:

- Improving facility/infrastructure without disturbing the ecosystem and by using local materials. Building paved roads and health facilities without damaging beauty and naturalness of the tourist attraction. Building hotels, home stays and tracking trails can damage the village through pollution and diminishing wild areas.

- Periodic capacity improvement for ecotourism administrators by maintaining the uniqueness and variety of local people's tradition and culture.

- Establishing ecotourism managing institutions supported by government or other parties. Local people should be directly involved as actors in ecotourism program for example as teacher, speaker, and assistant. Their skill should be trained and improved in order to meet the standard as administrators.

- Management and the property of facility/infrastructure and tourism area by local people. Hotel and home stays should be owned and managed by local people to ensure the tourist comfort and safety with ecofriendly environments.

- Tour guide shoul be from local people. The presence of tourists should not disturb flora and fauna in the tourist attractions.

- Cooperating with other parties and inviting investors to develop tourist village of Tete Batu. 
Table 2. Analysis of External Factors of Ecotourism Model at Natural Attractions in Tete Batu Village

\begin{tabular}{|c|c|c|c|c|}
\hline External Factors & weight & Rating & Score & Strategies \\
\hline \multicolumn{5}{|l|}{ Opportunities } \\
\hline $\begin{array}{l}\text { - Geographical position of Tete Batu } \\
\text { Village as a transit points for the } \\
\text { tourists to visit other attractions } \\
\text { Fast development of information and } \\
\text { communication technologies eases } \\
\text { tourists to directly search for } \\
\text { informationabout tourist attractions } \\
\text { - High potential and interest of the } \\
\text { tourists } \\
\text { Government's policy regarding halal } \\
\text { tourism give an opportunity to develop } \\
\text { the tourism }\end{array}$ & $\begin{array}{l}0,262 \\
0,172\end{array}$ & $\begin{array}{l}3 \\
3\end{array}$ & 0,476 & 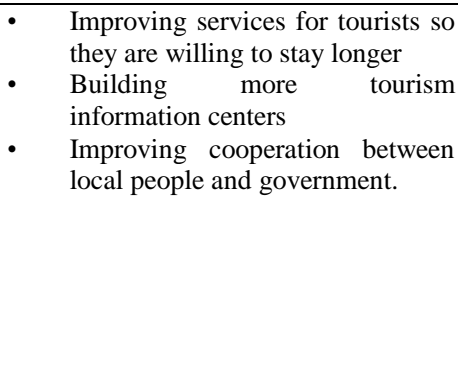 \\
\hline & 1,00 & & 3,566 & \\
\hline \multicolumn{5}{|l|}{ Threats } \\
\hline $\begin{array}{l}\text { - Lack of government attention to } \\
\text { improve transportation facility } \\
\text { Lack of security and safety of } \\
\text { tourist } \\
\text { A decrease of local people's } \\
\text { religious and cultural values } \\
\text { Lack of private and governmental } \\
\text { investments for developing tourist } \\
\text { attractions }\end{array}$ & $\begin{array}{l}0,251 \\
0,114 \\
0.114 \\
0,520\end{array}$ & $\begin{array}{l}4 \\
3 \\
4 \\
4\end{array}$ & $\begin{array}{l}1,004 \\
0,342 \\
0,456 \\
0,1\end{array}$ & $\begin{array}{l}\text { - Local government makes an effort } \\
\text { to improve transportation facility } \\
\text { Guarantee security and safety of } \\
\text { the tourists. } \\
\text { Improving religious and social } \\
\text { activities in the society } \\
\text { Managing investors to develop } \\
\text { tourist attractions. }\end{array}$ \\
\hline & $\mathbf{1 , 0 0}$ & & 1,902 & \\
\hline & & & 2,717 & \\
\hline
\end{tabular}

Ecotourism model is expected to become one of main activities of tourism program in Tete Batu Village by emphasizing fairness and sustainability and become an alternative income for local people. The existence of ecotourism is hoped to be able to maintain local people's economic independence and change their life quality. In utilizing and managing ecotourism, the people should use conservation approach in order to conserve their local tradition and culture. Finally, ecotourism needs local people's active role in it planning and management.

\section{Conclusion}

Based on analysis of ecotourism potential in Tete Batu Village, the model needs an organized management and connection between tourist attractions in Tete Batu Village in order to be easily accessed, naturally conserved and more attractive for tourists to visit the place. There needs to be a developments of road facility, hotel, home stay, or local hosts without diminishing the characteristics of natural countryside atmosphere. The development of ecotourism is aimed to improve appreciation and participation of local people and domestic/foreign tourists towards local nature and culture and to improve local economy. Local government should make a policy that support the role of society in ecotourism management.

\section{References}

BPS. (2016). Kabupaten Lombok Timur dalam Angka. Pemkab. L ombok Timur

Dirawan, Gurfan Darma (2008). Strategi Pengembangan Ekowisata. Jurnal Kepariwisataan Indonesia Jakarta

Dias Satria (2009). Strategi Pengembangan Ekowisata Berbasis Ekonomi Lokal Dalam Rangka Program Pengentasan Kemiskinan Di Wilayah Kabupaten Malang. Journal Of Indonesian Applied Economics. 
Doddy Soedigdo, Yesser Priono (2013). Peran Ekowisata Dalam Konsep Pengembangan Pariwisata Berbasis Msyarakat Pada Taman Wisata Alam (TWA) Bukit Tangkiling Kalimantan Tengah. Jurnal Perspektif arsitektur.

Edi Mulyadi, Nur Fitriani (2010). Konservasi Hutan Mangrove Sebagai Ekowisata. Jurnal Ilmiah Teknik Lingkungan UPN.

Freddi Rangkuti. (2005). Analisis SWOT Teknik Membedah Kasus Bisnis. PT Gramedia Pustaka Utama

Garrod B. (2003). Local Participation in the Planning and Management of Ecotourism. A Revised Model Approach. Journal of Ecotourism.

Marpaung Happy. (2000). Pengetahuan Kepariwisataan, Bandung Alfabeta

Moleong, J Lexy. 2005. Metodologi Penelitian Kualitatif, Bandung : PT Remaja Rosdakarya

Pidarta, Made. (2005). Perencanaan Pendidikan Parsipatori dengan Pendekatan Sistem. Jakarta: Rineka Cipta

Timothy, D.J., \& Olsen, H. (2006). Tourism, religion and spiritual journeys. Oxford: Routledge.

Tuwo A. (2011). Pengelolaan Ekowisata Pesisir dan Laut. Surabaya: Brilian Internasional. 